\title{
Michele Scobie, 2019, Global environmental governance and small states: architectures and agency in the Caribbean
}

\section{Edward Elgar Publishing, New Horizons in Environmental Politics series, Cheltenham, UK/Northampton, MA, USA, 212 p.}

\author{
Yann Bérard ${ }^{1}$ \\ Published online: 11 November 2019 \\ (C) The Author(s) 2019
}

This book aims to fill the gap in the literature on international relations and global environmental change by providing answers to the following questions in the Caribbean context: how are global institutional architectures and environmental norms adapted to local development priorities in the areas of tourism, ocean governance, energy, nature conservation, and trade? To what extent are the national development trajectories of Caribbean Small Island Developing States (SIDS) relevant from this perspective? What are the broader challenges and opportunities for the environmental governance of Caribbean SIDS in the future?

A lecturer and researcher at the Institute of International Relations and the Sir Arthur Lewis Institute for Social and Economic Studies at the University of the West Indies (UWI), St. Augustine, Michelle Scobie describes how unique historical, cultural, and economic contexts have added new levels of "complexity" to the way international environmental governance regimes and norms have been deployed in Caribbean SIDS or not. In doing so, the author highlights some of the power asymmetries and complex relationships between "new" private transnational actors (agencies, corporations, advocacy groups, NGOs, etc.) and these "small states," with the help of many illustrations (exploitation of natural resource, energy transition, "blue economy," etc.). Overall, the book reflects the richness and dynamism of the current ways in which Caribbean SIDS and non-state actors are trying to implement global environmental governance regulations or enhance local ones.

The examples in Global Environmental Governance and Small States come mainly from the English-speaking islands of the Caribbean, in particular Jamaica, Barbados, Saint Lucia, and Trinidad and Tobago. These territories share the "classic" environmental and economic vulnerabilities of SIDS, but along different economic

Yann Bérard

yann.berard@univ-antilles.fr

1 University of the French West Indies, Martinique, France 
development paths - the first three are largely dependent on tourism, while the latter's economy is more energy-based. The realities of environmental governance in these states appear, according to the author, to be representative of the Caribbean region. At the same time, many references are made throughout the book to regional governance structures and other states of the Caribbean Community (CARICOM) to which they belong. The methodology is based on data collection from semi-directive interviews with state and non-state environmental actors, both regional and international (government representatives, diplomats, private sector, NGOs), supplemented by the compilation of many documentary sources. In this review, we will emphasize the framing elements proposed by the author, while giving an overview of the empirical developments in the book and the main results that emerge from them.

As M. Scobie points out in the first introductory chapter, SIDS are not a homogeneous group, but they represent a unique group of states in the context of environmental governance due to the many challenges facing their economies and fragile environments. More precisely, they share small territorial areas, a significant concentration of infrastructures and populations in coastal parts, which make them particularly vulnerable to rising sea levels and invasive species. They also have limited financial, human, and technical resources, often undiversified industries, increased vulnerability and sensitivity to "exogenous" economic shocks, and limited resilience to frequent extreme climatic events (hurricanes, floods, droughts). The author recalls that the historical birth of SIDS dates back to the early 1990s with the formation of the Alliance of Small Island States (AOSIS), an ad hoc negotiating and lobbying group within the United Nations whose first objective was to defend their environmental interests, particularly in the face of climate change. In 1994, the first United Nations International Conference on Small Island Developing States was held and since then, every five years, SIDS have met and set their own sustainable development agenda. More broadly, M. Scobie intends to show how Caribbean SIDS are organizing themselves to face the great transformation related to the accelerated development of carbon societies, named "the Anthropocene"- a keyword in this chapter - by actively participating in global environmental governance.

Following this introductory chapter, the conceptual and normative framework of the book is explained in more detail. The author explicitly relates her analysis to the work on polycentric and multi-level environmental governance. As such, it proposes an interpretation grid based on five key variables of environmental governance: contexts, frameworks, power, quality, and norms. In doing so, the concept of complexity appears as a common thread of the book. Through this concept, M. Scobie seeks to include the multiple actors who operate in various fora by describing their relationships and agendas to develop "solutions" to the "problems" they share, following various forms of compliance with global institutional architectures and the implementation of related environmental norms. This conceptual and normative framework makes it possible to problematize regional governance in the context of Caribbean SIDS as a "subset" of global environmental governance. An important element of this governance concerns the "new" non-state actors (private sector and NGOs) who, as the author points out, often have more resources and capacities to influence international agendas, norms, and public opinion on environmental governance than SIDS themselves. Simultaneously, M. Scobie shows that SIDS are more mobilized than ever on environmental governance issues, particularly with regard to climate change. 
Based on this conceptual and normative framework, the author highlights six themes of particular importance to Caribbean SIDS, each of which is the subject of a separate empirical chapter: sustainable tourism, climate change, marine and ocean governance, renewable energy and energy security, cultural and natural heritage, and tradeenvironment nexus. All these themes are carefully examined on the basis of the reading grid proposed by the author, whose analysis regularly includes back and forth between global and local scales. It would of course take too long to summarize each of them one by one here, as they are so rich in lessons and research perspectives. On the whole, one can only be struck by the diversity of initiatives and actions undertaken by multiple state and non-state actors in the region. In most cases, CARICOM appears to be a central actor, which often acts as a "bridge" between international agencies and nonstate environmental actors.

This leads M. Scobie to draw future trends characterized by both strengths and weaknesses, as a few examples will illustrate: the rise of the tourism industry in Caribbean SIDS calls for greater efforts to unfold integrated environmental protection and sustainable energy policies, while there is often a lack of legislation, resources, or simply political will, in these domains; similarly, the 2015 Paris Agreement to net-zero emissions target for 2050, as pointed out by the author, certainly do not lead to stopping the effects of climate change in Caribbean SIDS, which probably more than anywhere else requires redoubling endeavors to invent regional and national adaptation and damage financing policies - the issue of climate justice being of great importance here; in another register, the governance of cultural and natural heritage in Caribbean SIDS is also affected by strong tensions between the objective of developing and preserving local communities and the current "neoliberal" slope of commodification of nature, which attempts to regulate biological products and their trade in a more ethical way do not make disappear. In a short final chapter, M. Scobie provides a synthesis of these analyses and links them to ongoing research on global environmental governance - the work of Frank Biermann's team on Earth System Governance (ESG) then appears as an essential reference for the author.

This book, which is very substantial in analytical terms and of great empirical value, largely meets the ambitions stated by the author. In addition, one can only welcome that M. Scobie's writing always remains simple and easy to access despite the intertwining of many of the issues analyzed. Before concluding, a brief remark can be made, however, regarding the thematic division of the empirical chapters. Alongside climate change, whose "pervasiveness" is well reflected in all the chapters, it appears questionable whether other areas and regimes should not also have a voice. This is particularly true for agriculture and food security, a key cross-cutting issue of the economy and policies of most Caribbean SIDS, that has long been invested by international and regional agencies. Singularly exposed and sensitive to global environmental changes (from climatic events to chemical pollutions), agriculture appear in the region as a sector where the challenges of resilience, sustainability, and capacity-building have grown considerably in interest over the last few years, as shown by the reports of the Caribbean Agricultural Research and Development Institute (CARDI), for example. Although mentioned by the author on several occasions, this issue could probably have been more prominent in the book by being the subject of further development, or even an additional chapter. 
Global Environmental Governance and Small States is no less a valuable and indispensable reference for all those interested in global environmental change in the Caribbean. At least, two reasons can be put forward for this: First, because this work lays essential thematic foundations for empirical research in international relations in a region of the world where there is still too little synthesis work; second, because political science research on state transformations in response to global environmental change and "Anthropocene politics" here should only gain in interest (and undoubtedly urgency) in the years to come - as evidenced by the major hurricanes of recent years or the current Sargassum "crisis," for instance. Whether we are pleased or not, the Caribbean has become an exceptional laboratory for analyzing global environmental change, calling more than ever for being scrutinized by "new generations" of environmentalists - practitioners as experts, students as lecturers and researchers. This is why the reading of this unique book is to be welcomed and encouraged.

Open Access This article is distributed under the terms of the Creative Commons Attribution 4.0 International License (http://creativecommons.org/licenses/by/4.0/), which permits unrestricted use, distribution, and reproduction in any medium, provided you give appropriate credit to the original author(s) and the source, provide a link to the Creative Commons license, and indicate if changes were made. 